\title{
EFFECTS OF SPENT ENGINE OIL ON THE GERMINATION AND GROWTH OF JATROPHA CURCAS SEEDS
}

\author{
Donatus, F.N.; Akogwu, R.D.; Amuta, E.U. and Aguoru, C. U.
}

Federal University of Agriculture, Makurdi, Benue State, Nigeria.

DOI: https://doi.org/10.51193/IJAER.2021.7312

\begin{abstract}
This study investigated the effects of spent engine oil on the germination and growth parameters of Jatropha curcas. Jatropha curcas was grown on soils contaminated with $5 \mathrm{ml}, 10 \mathrm{ml}$ and $15 \mathrm{ml}$ of spent engine oil to obtain $0.25,0.5$ and $0.75 \%$ contaminations respectively. The study was carried out for 80 days after planting and growth parameters such as germination percentage, leaf area, number of leaves and stem height were assessed at twenty day intervals for the entire duration. Results showed that the germination percentage, mean leaf number, leaf area and plant heights of Jatropha curcas decreased with increasing level of contamination with spent engine oil. The highest mean leaf number (15.0) and stem height (16.7) were recorded for the control. A significant difference $(\mathrm{P} \leq 0.05)$ in plant height, leaf area and leaf number was observed in the control when compared to the contaminated samples. The plants in the contaminated samples showed phytotoxicity (yellow leaf coloration, stunted growth) which was not observed in the control. In summary, spent engine oil had negative impacts on the germination and growth of Jatropha curcas.
\end{abstract}

Keywords: Soil contamination, Spent engine oil, Jatropha curcas

\section{INTRODUCTION}

Soil contamination resulting from indiscriminate disposal of spent engine oil (a chemical complex of petroleum hydrocarbons) is a widespread phenomenon which has drawn the attention of the research community on a global scale. It is common in every major city across the globe. This may pose a great threat to theenvironment and human beings at large ${ }^{[1]}$.

Spent engine oil is usually obtained after servicing and subsequently draining used oil from automobiles and generator engine. The disposal of spent oil into gutters, water drains, open 
International Journal of Agriculture and Environmental Research

ISSN: 2455-6939

Volume: 07, Issue: 03 "May-June 2021"

vacant plots and farmlands in Nigeria is a common occurrence and is mostly done by automechanics and allied artisans with workshops on the roadside and open places. The disposal of used oil indiscriminately to the soil affects its physical, biological and chemical properties, therefore making life uncomfortable for both plants and animals that live and feed in the soil including Jatropha curcas ${ }^{[11]}$.

The results from previous study showed that there was a significant difference $(\mathrm{P} \leq 0.05)$ observed in the growth parameters (plant height, number of leaves, leaf area, biomass) of Jatropha curcas seedlings grown on spent engine oil contaminated soil when compared with seedlings grown on uncontaminated soil ${ }^{[11]}$. Similar results were also reported by other researchers on the reduction in the mean leaf number, leaf area and plant heights of Telferia occidentalis and Moringa oleifera with increasing level of contamination with spent engine oil ${ }^{[15,17]}$.It was further stated that the growth response of these plants in thecontaminated pots differed significantly $(\mathrm{P} \leq 0.05)$ from those in the control pots.

Jatropha curcas also known as Physic nut or Jarak Pagar (Malaysia) is a non-edible oil crop that belongs to the Euphorbiaceae family. It is native to Central America but widely planted throughout the arid, semi-arid and tropical regions globally for the production of biodiesel ${ }^{[16]}$.

It was cited as the cheapest source of biodiesel feedstock and has shorter gestation period of 2 years compared to 3 years in oil palm. Jatropha curcas is one of the most commonly used oils for producing biodiesel ${ }^{[18,16]}$. Jatropha was promoted due to its hardiness, the ability to grow on marginal lands and thus not compete for land with food crops. It grows easily, rapidly, propagated without difficulty, reasonably high-yielding and has an economic life span of about 30 years [16].

Research has been carried out on the effects of spent engine oil on the growth of some plants ${ }^{[14,17,15]}$, but information on the effects of spent engine oil on the germination and growth of Jatropha curcas in soils amended with NPK (20:10:10) fertilizer and poultry droppings based on literature review has not been widely explored. It is on this basis that this study was carried out.

\section{MATERIALS AND METHODS}

\subsection{Study area/Sample collection}

The study was carried out in Makurdi, Benue State. Soil samples were collected at an open farmland along Uni-Agric road, Northbank with the following geographical coordinates, latitude $\mathrm{N} 07^{\circ} 45^{\prime} 11.088^{\prime \prime}$ of the equator, longitude E $08^{\circ} 32^{\prime} 46.8^{\prime \prime}$ and an altitude of $103.0 \mathrm{~m}$ of the meridian using Garmin GPS map 76Cx. 
Spent engine oil was collected from a local auto-mechanic workshop in Northbank while Jatropha curcas seeds were collected from Sam Agro Global Services, Makurdi.

\subsection{Assessment of Selected Growth Parameters of Jatropha curcas}

After planting three viable Jatropha curcas seed at 2-4 cm depth with the caruncle oriented downwards ${ }^{[9,10]}$, the following growth parameters were assessed for eighty days at twenty day intervals. These include seed germination percentage, number of leaves, Leaf area $\left(\mathrm{cm}^{2}\right)$ and stem height $(\mathrm{cm})$.

Below are the detailed methodologies for assessing each growth parameter.

- Germination percentage: For Jatropha plants, the expected duration for germination is between two to ten days ${ }^{[15]}$. The growth percentage was determined by calculating the ratio of the number of germinated seeds to the number of seeds planted, multiplied by one hundred ${ }^{[15]}$.

The equation is given below as;

$\%$ Germination $=$ Number of germinated seeds $\quad X 100$

Number of seeds planted

- Stem height: The stem height was determined by measuring the distance from the top soil to the first terminal bud using a meter rule. Results were recorded in centimeters.

- Number of leaves: The total number of leaves was determined by manually counting the leaves per plastic bucket and taking the average per treatment [17].

- Leaf area: The leaf area was determined by measuring the length and width (at the widest point) of each leaf. The product of this was multiplied by a correction factor of 0.75 to cater for leaf shape ${ }^{[14,15}$ and 17$]$. The formula is given below;

Leaf area $\left(\mathrm{cm}^{2}\right)=(\mathrm{L} \times \mathrm{B}) \times 0.75$.

Where; $\mathrm{L}=$ length, $\mathrm{B}=$ breadth and correction factor $=0.75$.

\subsection{Experimental set-up and seed planting}

The design of the experiment is complete randomized block design (CRBD) with three treatments and five replications. Contamination of soil samples was done by thoroughly mixing the soil 
with different levels of spent engine oil in their respective plastic buckets ${ }^{[15]}$.

Soil samples of $2 \mathrm{~kg}$ in each of the plastic buckets were treated with $5 \mathrm{ml}, 10 \mathrm{ml}$, and $15 \mathrm{ml}$ of spent oil to obtain $0.25,0.5$, and $0.75 \%(\mathrm{w} / \mathrm{w})$ contamination levels respectively. The choice of the contamination levels was in order to achieve slight contamination of the soil samples. Three (3) viable Jatropha curcas seeds alongside the control were planted in each bucket laid out in the field and watered to field capacity at three days interval to maintain moisture content ${ }^{[6]}$. Below is a tabular representation of the experimental design.

\section{Table 1: Details of the experimental Design}

\begin{tabular}{ll}
\hline $\begin{array}{c}\text { Sample } \\
\text { details }\end{array}$ & Sample \\
\hline $\boldsymbol{A}$ & Soil $(2 \mathrm{~kg})+\mathrm{SEO}(5 \mathrm{ml})+$ Jatropha seeds \\
$\boldsymbol{B}$ & Soil $(2 \mathrm{~kg})+\mathrm{SEO}(10 \mathrm{ml})+$ Jatropha seeds \\
$\boldsymbol{C}$ & Soil $(2 \mathrm{~kg})+\mathrm{SEO}(15 \mathrm{ml})+$ Jatropha seeds \\
Control & Soil $(2 \mathrm{~kg})+$ Jatropha seeds \\
\hline $\mathrm{n}=5$, SEO $=$ & Spent Engine oil.
\end{tabular}

\subsection{Statistical analysis}

Data collected were subjected to one-way analysis of variance (ANOVA) with Statistical Package for Social Sciences (SPSS) version 20.0.

\section{RESULTS AND DISCUSSION}

\subsection{Germination percentage of Jatropha curcas in Treatmentand Control Soil Samples}

The germination percentage reduced with increase in spent engine oil contamination levels. The highest and lowest values (60\% and 20\%) were observed in $5 \mathrm{ml}(0.25 \%)$ and $15 \mathrm{ml}(0.75 \%)$ contamination levels respectively, while $40 \%$ was recorded in the control samples as shown in table 2 below.

This agrees with previous findings of reduced emergence/growth rates in Jatropha curcas and fluted pumpkin respectively with increased spent oil contamination of soil samples ${ }^{[12,15]}$. In one research for instance, $83.3 \%$ and $8.33 \%$ germination rates were observed in $20 \mathrm{ml}$ and $100 \mathrm{ml}$ SEO contamination per $2 \mathrm{~kg}$ soil samples respectively ${ }^{[15]}$. Although, $40 \%$ emergence rates were 
recorded in the control pots as against the $100 \%$ reported in another study ${ }^{[15]}$. This might be attributed to the differences in the physiological response of both plants to the contaminant.

Table 2: Mean Germination Percentage of Jatropha Seeds.

\begin{tabular}{cc}
\hline Sample & Germination Percentage $(\% \mathrm{G})$ \\
\hline A & 60 \\
B & 40 \\
C & 20 \\
Control & 40 \\
\hline
\end{tabular}

\subsection{Stem height of Jatropha curcas in Treatment and ControlSoil Samples}

The results in Figure 1 below show that there was a reduction in the stem heights of Jatropha curcas with increase in contamination levels ${ }^{[15,13]}$. The highest and lowest values at $61-80$ days were $16.7 \mathrm{~cm}$ and $12.6 \mathrm{~cm}$ in control and $15 \mathrm{ml}$ contamination levels respectively. This affirms that spent engine oils negatively impacts the growth of Jatropha curcas ${ }^{[1,15]}$.

Fig. 1: Shows a graphical representation of the mean values of stem height (cm) of Jatropha curcas from 0-80 days.

Stem Height Mean Values of Jatropha curcas.

20

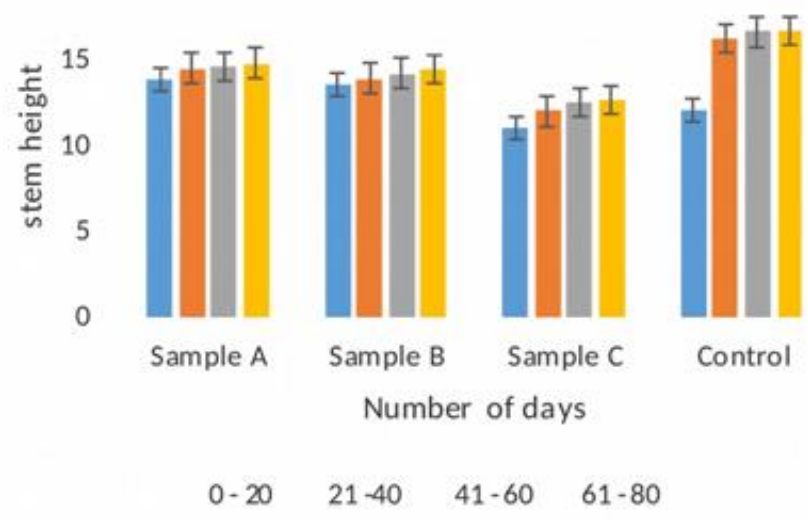




\subsection{Number of leaves of Jatropha curcas in Treatment andControl Soil Samples}

The results as shown in figure 2 below reveal that the number of leaves reduced with increase in contamination levels. Mean values of 11 and 9 were recorded in $5 \mathrm{ml}$ and $15 \mathrm{ml}$ contamination levels respectively. The highest mean value (15) was recorded in the control samples. This agrees with previousreports and affirms that spent engine oil has negative impacts on the growth of Jatropha curcas.

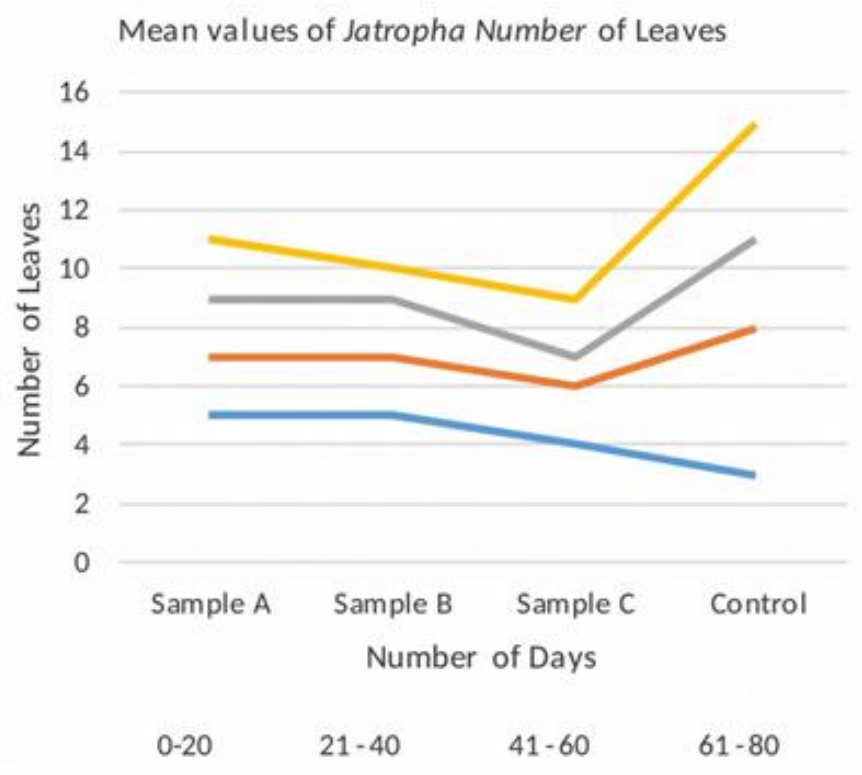

\section{Fig. 2: Shows a graphical representation of the mean values of number of leaves of jatropha curcas from 0-80 days.}

\subsection{Leaf area $\left(\mathrm{cm}^{2}\right)$ of Jatropha curcas in Treatment and Control Soil Samples}

The results as shown in figure 3 below reveal that there is a highly significant difference in the leaf area of all the treatments. The values reduced with increased spent engine oil contamination as reported by previous researchers ${ }^{[5,12]}$. Similar results were reported when fluted pumpkin was used ${ }^{[15]}$. The highest leaf area $\left(38.8 \mathrm{~cm}^{2}\right)$ was recorded in the control. 
International Journal of Agriculture and Environmental Research

ISSN: 2455-6939

Volume: 07, Issue: 03 "May-June 2021"

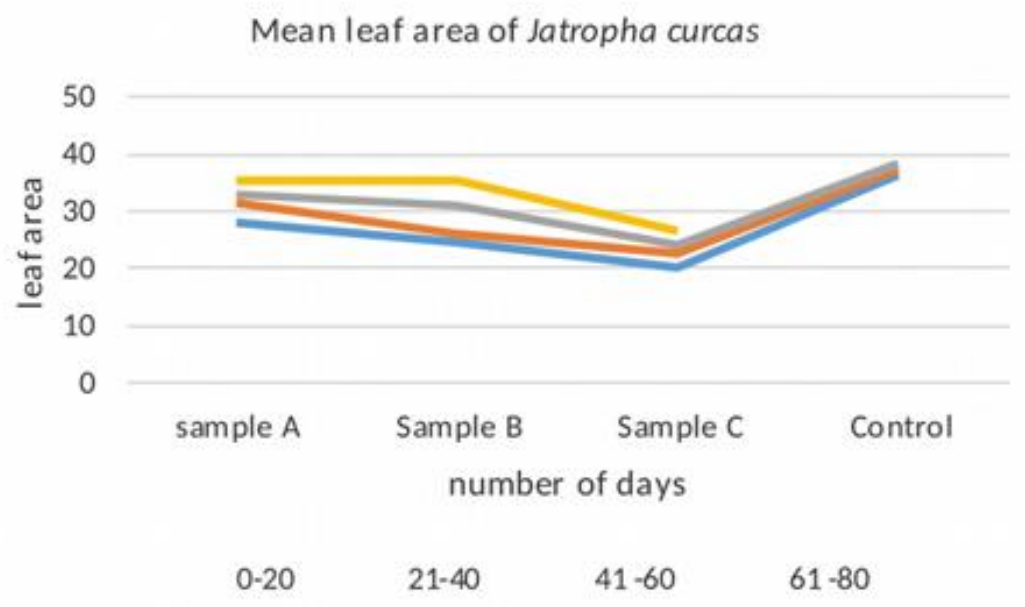

Fig. 3: Shows graphical a representation of the mean values of leaf area $\left(\mathrm{cm}^{2}\right)$ of Jatropha curcas from 0-80 days.

\section{CONCLUSION}

In conclusion, this study demonstrates that spent engine oil has negative effects on the germination and growth of Jatropha curcas, therefore, soils should be guarded against pollution most especially in areas where farming activities takes place on a large scale such as Makurdi, Benue State.

\section{REFERENCES}

[1] P. Agamuthu, O.P. Abioye and A. Abdul Aziz, Phytoremediation of soil contaminated with used lubricating oil using Jatropha curcas, Journal of Hazardous Materials, Vol. 1, No.9 (2010): 891-894.

[2] R.K. Kannaujia and S. Singh, Effect of different fertilizers on the growth of Jatropha curcas seedlings, International Journal of Chemical Sciences, Vol. 11,No.1(2013),487502.

[3] E.O. Ngwu, The effects of organic and inorganic fertilizers on the growthand yield of physic nut (Jatropha curcas) .International Journal of Advances in Agriculture and Environmental Engineering, Vol. 3, No.1, (2016).

[4] A. C. Onwu, N. D. Osujieke, A. T. Gani and A. Ali, Influence of Organic Fertilizer (Nomau on Soil, Leaf Nutrient Content, Growth and Yield of PhysicNut (Jatropha 
curcas) in Makurdi, North Central, Nigeria. Asian Journal of Soil Science and Plant Nutrition, Vol. 3, No. 2, (2018), 1-11.

[5] M. Waziri, U. Abdullahi, A. A. Audu, and Kalimullah, Phytoremediation Potentials of Selected Plants in Industrially Contaminated Soils. International Journal of Environmental Science and Development, Vol. 7, No. 10, (2016).

[6] O.M. Agbogidi, N. A. Adim, and J. Akintunde, Effects of Kerosene Contaminated Soil on the Growth of Maize (Zea mays L.). Journal of Agriculture and Food Environment, Vol. 3, No. 2(2016), 84-91.

[7] B. O. Okonokhua, B. Ikhajiagbe, G. O. Anoliefo, and T. O. Emede, The Effects of Spent Engine Oil on Soil Properties and Growth of Maize (Zea mays L.),Journal of Applied Science and Environmental Management, Vol. 11, No.3 (2007), 147 - 152.

[8] W.M.J. Achten, L.Verchot, Y.J. Franken, E. Mathijs, V.P. Singh, R. Aerts and B. Muys, Jatropha bio-diesel production and use. Biomass and Bioenergy, Vol.32, (2008), 1063-1084.

[9] R. Brittaine and N. Lutaladio, Jatropha: A small-holder bioenergy crop, Integrated crop management Open Access, 1:1(2010),.ISSN;1020-4555.

[10] P. Srimathi and M. Paramathma, Influence of seed management techniques for production of quality seedlings in Jatropha. In: Singh, B., Swaminathan, R. \& Ponraj, V., (eds). Proceedings of the biodiesel conference toward energy independence - focus of Jatropha, Hyderabad, India, June 9-10. New Delhi: Rashtrapati Bhawan; (2006), pp. $158-178$.

[11] O.M. Agbogidi, and P.G. Eruotor, Morphological Changes Due to Spent Engine Oil Contamination and Its Heavy Metal Components of Jatropha curcas Linn seedlings, International Conference on Bioscience, Biotechnology and Healthcare Sciences, (2012). Pp: 88-90.

[12] O.M. Agbogidi, E.M. Ilondu and O. H. Avwenagha, Growth response of Jatropha curcas (Linn.) seedlings grown in spent engine oil contaminated soil. International Journal of Forest, Soil and Erosion, Vol. 4 No.4(2013), 114-118.

[13] O.D. Idowu and O.O. Fayinminnu, Phytotoxicity effects of spent engine oil in Jatropha curcas seedlings used for phytoremediation. Ethiopian Journal of Environmental Studies \& Management, Vol.8, No. 2 (2015), 906 - 915, 2015. 
[14] B. O. Okonokhua, B. Ikhajiagbe, G. O. Anoliefo and T. O. Emede, The Effects of Spent Engine Oil on Soil Properties and Growth of Maize(Zea mays L.),Journal of Applied Science and Environmental Management, Vol. 11, No.3, 147 - 152.

[15] K.C. Onwusiri, C.U. Aguoru and G.F. Akomolafe, Effect of spent engine oil on germination and growth parameters of fluted pumpkin (Telferia occodentalis) in Makurdi, Journal of research in Forestry, Wildlife and Environment,Vol. 9, No. 4, (2017), ISBN: $2141-1778$.

[16] M. Mandy, P. H.Wong, H. K. Huong, K. Julius and K. C. Liew , Growth responses of varieties of Jatropha curcas seedlings to varying NPK fertilizer rates, International Journal of Agriculture, Forestry and Plantation, Vol. 5, (2017), ISSN: 2462-1757.

[17] O.M. Agbogidi and E.M. Ilondu, Effects of spent engine oil on the germination and seedling growth of Moringa olifera (Lam.). Scholarly Journal of Agricultural Science, Vol. 3, No.6, (2013). pp. 239-243.

[18] A. B. Chhetri, S. T. Martin, S. M. Budge, K. C. Watts, and M. R. Islam, Non-Edible Plant Oils as New Sources for Biodiesel Production, International Journal of Molecular Sciences Vol. 9, (2008). 169-180. 